KREATIF

Jurnal Ilmiah

Prodi Manajemen Universitas Pamulang
ISSN : $2339-0689$, E-ISSN : 2406-8616

J. KREATIF, Vol. 8, No.1, Juni 2020 (Halaman 91-103)

Tersedia Online di: http://openjournal.unpam.ac.id/index.php/kreatif

\title{
TRANSFORMASI SUMBER DAYA MANUSIA MENGHADAPI PASAR TENAGA KERJA ERA REVOLUSI INDUSTRI 4.0
}

\author{
Emillia $^{1}$, Dwina Kuswadani ${ }^{2}$, Dhami Johar Damiri ${ }^{3}$ \\ ${ }^{1}$ Program Studi Diploma III Teknik Mesin, Fakultas Teknologi dan Bisnis Energi, \\ Institut Teknologi PLN, Jakarta, Indonesia ${ }^{1}$ \\ ${ }^{2}$ Program Studi Teknik Informatika, Fakultas Telematika Energi, Institut \\ Teknologi PLN, Jakarta, Indonesia ${ }^{2}$ \\ ${ }^{3}$ Program Studi Magister Teknik Elektro, Fakultas Energi dan Ketenagalistrikan, \\ Institut Teknologi PLN, Jakarta, Indonesia ${ }^{3}$ \\ E-mail: emillia@itpln.ac.id ${ }^{1}$, dwina@itpln.ac.id ${ }^{2}$, dhami@itpln.ac.id ${ }^{3}$
}

\begin{abstract}
ABSTRAK
Jurnal ini menggunakan prosedur research berupa proses analisa dengan cara melakukan tinjauan kepustakaan melalui pradigma analisa pemaparan dan gambaran yang rinci,metode interview dilakukan dengan cara question and answer yang diajukan kepada para ahli yang mendalami transformasi sumber daya manusia (SDM) dan sejarah perkembangan generasi millenial. Indonesia sedang dalam proses melalui periode revolusi industri 4.0 dimana terjadi perkembangan digital dalam segala aspek kehidupan terutama di bidang lapangan pekerjaan yang mengakibatkan hilangnya berbagai jenis pekerjaan yang disertai dengan timbulnya lapangan pekerjaan baru

. Oleh karena itu untuk mengatasi persaingan tenaga kerja diperlukan adanya pengembangan dan transformasi kemampuan sumber daya manusia (SDM) sebagai calon pekerja yang akan memasuki kompetisi market lapangan kerja.

Para calon tenaga kerja dalam periode tersebut harus menjadi literasi pekerja baru yang memiliki kemampuan melakukan analisa data dengan luas dan terperinci dan juga kemampuan menarik kesimpulan yang memiliki relasi dengan kecakapan berkomunikasi, bekerjasama (team work), tanggap, produktif dan inovatif, sehingga dalam periode revolusi industri 4.0 tersebut akan menciptakan penduduk yang makmur, sedangkan perubahan intelekual akan menciptakan manusia menjadi tangguh dan superior.
\end{abstract}

Keywords : Sumber Daya Manusia; Persaingan; Pasar Tenaga Kerja

\section{ABSTRACT}

This journal uses a research procedure in the forms of an analysis process by conducting a literature review through a detailed analisis and exposure paradigm, an interview method conducted by way of question and answer submitted to experts who are deepening the transformation of human resources $(H R)$ and the history of the development of millennial generation.

Indonesia is in the process of going through a period of industrial revolution 4.0 where digital developments occur in all aspects of life, especially in the field of employment, resulting in the loss of various types of work accompanied by the 
emergence of new jobs. Therefore, to overcome labor competition, it is necessary to develop and transform the capabilities of human resources $(H R)$ as prospective workers who will enter the labor market competition.

Prospective workers in this period must be literacy of new workers who have the ability to analyze data in a broad and detailed manner and also the ability to draw conclusions related to communication skills, team work, responsiveness, productive and innovative so that in the revolutionary period industry 4.0 will create a prosperous population, while intellectual change will create a tough and superior human being.

Keywords : Human Resources; Competition, Labor Market

\section{PENDAHULUAN}

Istilah kata "revolusi industri" pertama kali dipergunakan oleh Friedrich Engels dan Louis Auguste Blanqui pada pertengahan abad ke19. Pengertian revolusi industri adalah transformasi secara integral dan fundamental menjadi pola kehidupan yang lebih sejahtera dan modern di berbagai aspek kehidupan, seperti pertanian, manufaktur (pabrikasi), pertambangan, teknologi, transportasi dan ekonomi yang merupakan dampak dari kemajuan di bidang ilmu pengetahuan dan teknologi (Alamsyah, November 2018).

Revolusi industri di dunia pertama kali terjadi pada tahun 1750-1850 di Inggris yang kemudian terjadi di negara-negara lain di Eropa (Hoedi Prasetya, Wahyudi Sutopo, Januari 2018). Revolusi ini diawali dengan ditemukannya mesin uap di bidang industri yang menggantikan tenaga kerja hewan dan manusia pada industri tekstil dan industri besi baja. Penemuan mesin uap tersebut menyebabkan meningkatnya penggunaan batu bara seiring dengan dibangunnya jalan raya dan jalur kereta api (Baiquni, Januari 2009).

Penemuan mesin uap tersebut diikuti dengan kemajuan mesin pembakaran dalam dan penemuan pembangkitan ketenagalistrikan bagi manufaktur, sehingga mengakibatkan meningkatnya secara pesat migrasi populasi dari daerah pedesaan menuju wilayah perkotaan yang mengakibatkan kota-kota di Eropa berkembang pesat pada awal abad pertengahan.

Salah satu aspek yang menyebabkan berlangsungnya revolusi industri di Inggris, yaitu disebabkan oleh perkembangan di bidang ilmu pengetahuan dan teknologi yang pesat pada awal abad ke 16 yang dipelopori oleh beberapa orang ahli, seperti Francis Bacon, Rene Descartes, Galileo Galilei yang disertai dengan peningkatan pengkajian dan riset yang dilakukan oleh beberapa institusi, seperti The Royal Improving Knowledge, The Royal Society of England dan The French Academy of Science dan pada waktu itu didukung juga dengan situasi politik beserta negara jajahan Inggris yang jumlahnya cukup banyak dan mempunyai kekayaan alam yang melimpah.

Indonesia pun mengalami pula revolusi industri yang terdiri atas beberapa periode seperti yang disajikan dalam Gambar 1 berikut, yaitu:

1. Periode pertama disebut revolusi industri 1.0 yang diawali dengan pengembangan mesin-mesin, penggunaan tenaga air dan uap.

2. Periode kedua disebut revolusi industri 2.0 merupakan fase produksi massal dengan memperhatikan quality control dan standar hasil produksi barang.

3. Periode ketiga disebut revolusi industri 3.0 pada saat tersebut Indonesia memasuki era komputerisasi. 
4. Periode keempat disebut revolusi industri 4.0 merupakan dimulainya periode digital dan otomatisasi internet berbasis manufaktur dan industri.

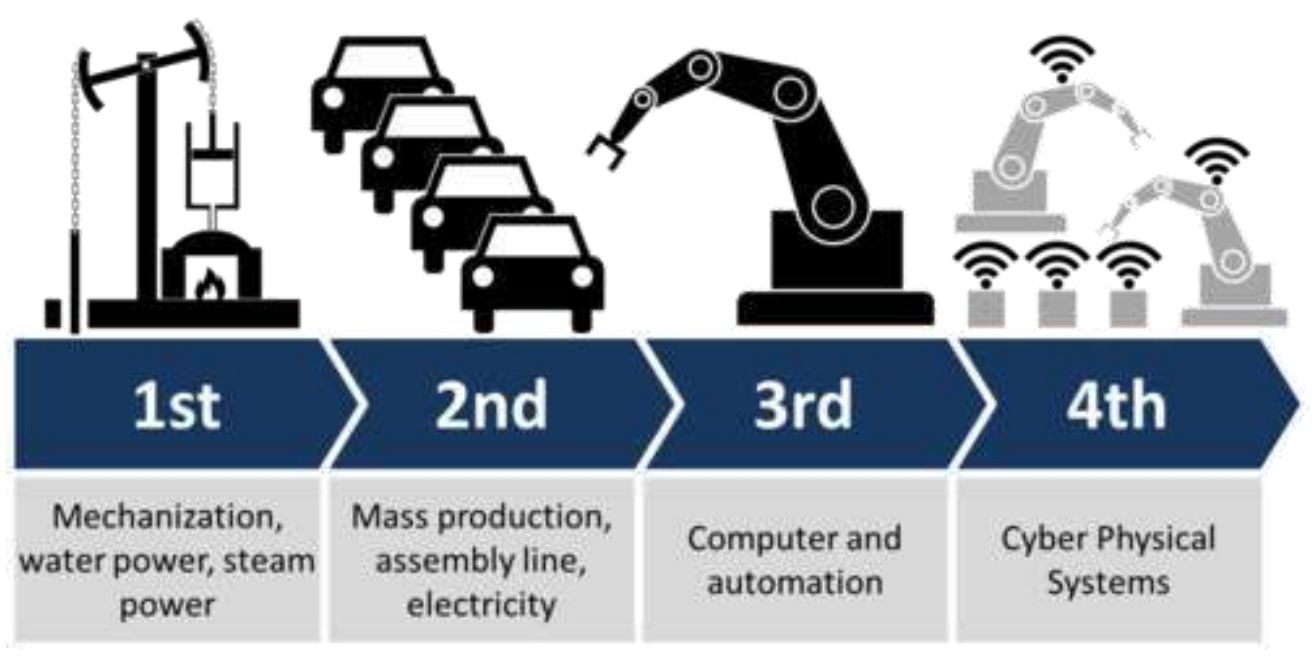

Gambar 1. Revolusi Industri

Revolusi industri 4.0 yang merupakan perubahan teknologi yang dapat diprediksi di masa yang akan datang. Perkembangan terobosan mekanisasi, seperti computer yang canggih, kecerdasan buatan (robotic artificial intelegency) dan perubahan genetika yang menyebabkan perubahan terhadap alam semesta (Suwardana, 2017). Setiap negara harus dapat menanggapi perubahan tersebut secara seksama yang melibatkan pejabat politik mulai dari sektor publik, swasta, golongan akademisi sampai masyarakat umum. Wolter mengatakan bahwa tantangan yang terjadi pada masa industri 4.0 dapat berupa :

1. Permasalahan security di bidang teknologi informasi.

2. Kemampuan dan stabilitas mesin-mesin produksi barang.

3. Kemampuan/kompetensi dan ketrampilan yang baik.

4. Para pejabat politik yang tidak bersedia berubah dan mengikuti perkembangan kemajuan teknologi.

5. Menghilangnya berbagai lapangan kerja tertentu.

Oleh karena itu dalam hal tersebut harus dilakukan pemetaan lapangan kerja yang akan lenyap pada periode revolusi industri 4.0. Hal ini merupakan kegiatan yang harus dilakukan untuk meminimalkan permasalahan pengangguran yang akan terjadi akibat hilangnya berbagai lapangan pekerjaan tertentu. Berdasarkan Work Employment and Social Outlook Trend 2017 memperkirakan bahwa besarnya pengangguran di Indonesia pada tahun 2018 sebesar 204 juta jiwa. Sedangkan menurut informasi dari Biro Pusat Statistik besarnya tunakarya di Indonesia pada tahun 2017 mencapai jumlah 5,33\% atau sebesar 7,01 juta jiwa dari sebesar 131,55 juta orang yang merupakan angkatan kerja.

Menurut Biro Pusat Statistik tingkat pengangguran tersebut berasal dari mereka yang merupakan tamatan Sekolah Menengah Kejuruan (SMK) dengan jumlah 9,27\%, Sekolah Menengah Atas (SMA) dengan jumlah 7,03\%, Diploma III sebesar 6,35\% dan perguruan tinggi dengan jumlah 4,98\%. Kondisi yang demikian diakibatkan oleh kurangnya keterampilan khusus berupa soft skill yang dimiliki oleh calon pekerja tersebut. Sehinga dengan demikian persoalan mereka yang 
digolongkan tidak memiliki pekerjaan atau tunakarya tersebut bagi Indonesia menjadi persoalan yang harus diperhatikan secara serius oleh Indonesia.

Permasalahan Indonesia juga diperberat dengan adanya prediksi bahwa pada tahun 2030 sampai dengan tahun 2040 jumlah populasi yang digolongkan ke dalam usia angkatan kerja produktif menjadi lebih banyak apabila dibandingkan dengan besarnya populasi yang tidak produktif. Diperkirakan mencapai sebesar 64\% dari jumlah seluruh populasi masyarakat Indonesia atau berjumlah sebesar 297 juta jiwa. Dengan demikian, maka populasi yang digolongkan sebagai usia pekerja produktif tersebut berkewajiban memiliki kemampuan yang lebih baik sehingga dapat bersaing dalam lapangan pekerjaan yang tersedia.

Dengan demikian transformasi yang berlangsung pada periode revolusi industri memiliki pengaruh terhadap kualitas angkatan kerja sebab keterampilan yang diperlukan juga akan berubah (Maemunah, Sabtu, 29 September 2018). Oleh sebab itu permasalahan yang utama adalah bagi berkembangnya atau tidak berkembangnya warga negara suatu negara merupakan permasalahan angkatan kerja. Kualitas tenaga kerja Indonesia pada saat ini sebagian besar berada pada tingkat dengan kemampuan yang kurang baik. Hal tersebut disebabkan hanya segelintir penduduk Indonesia yang mampu menempuh jenjang pendidikan yang baik dikarenakan oleh ketidakmampuan faktor ekonomi, sehingga penduduk tersebut hanya bergantung pada kekayaan alam saja, sementara itu sumber utama lainnya kurang produktif.

Berdasarkan uraian yang telah dikemukakan tersebut di atas bahwa angkatan kerja yang tersedia harus mempunyai kemampuan dan keterampilan yang sejalan dengan kemajuan teknologi dalam periode revolusi industri 4.0. Maka hal tersebut mendorong tim peneliti mencoba menyumbangkan pemikirannya mengenai peningkatan kemampuan dan tranformasi sumber daya manusia (SDM) Indonesia yang harus dimiliki oleh para calon tenaga kerja agar dapat bersaing dengan tenaga kerja lain dalam rangka revolusi industri 4.0.

Oleh karena itu untuk mendukung pembangunan Indonesia yang berkelanjutan maka perlu dicari suatu cara untuk melakukan transformasi kemampuan sumber daya manusia (SDM) Indonesia yang harus dikembangkan dalam rangka menghadapi pasar tenaga kerja dalam rangka revolusi industri 4.0. Selanjutnya maka yang menjadi pokok permasalahan dalam penelitian ini adalah sampai sejauh mana pembentukan karakter dan kompetensi yang harus dimiliki oleh sumber daya manusia (SDM) Indonesia dalam rangka persaingan pasar tenaga kerja pada revolusi industri 4.0 ? Berdasarkan permasalahan tersebut di atas dari hasil penelitian ini penulis berharap dapat menyumbangkan pemikirannya sehingga dapat membantu mengatasi permasalahan pemerintah di bidang pengangguran.

\section{METODE PENELITIAN}

Penulisan jurnal ini menggunakan metode penelitian dengan cara melakukan analisa terhadap berbagai sumber kepustakaan yang berhasil dikumpulkan untuk melakukan analisa secara deskripsi terperinci yang bertujuan untuk memperkuat analisis dari data yang diperoleh melalui metode interview dengan cara question and answer yang ditujukan kepada para ahli yang berkompeten di bidang pendidikan sumber daya manusia (SDM). Dengan demikian diharapkan melalui metode yang telah disebutkan di atas dapat dijadikan dasar dalam mengembangkan bidang ilmu secara teoritis mengenai transformasi sumber daya manusia (SDM). 
Selanjutnya dapat dipergunakan juga sebagai sumber pedoman bagi perkembangan ilmu pengetahuan dan teknologi, terutama dalam lingkup pembelajaran dalam rangka mengubah cara berpikir manusia Indonesia agar mampu menciptakan hasil karya yang unggul dalam rangka memenuhi kepentingan masyarakat pada periode revolusi 4.0

\section{HASIL DAN PEMBAHASAN}

Pada periode revolusi industri 4.0 mempunyai dampak bagi berbagai bidang kehidupan penduduk, berupa bidang perekonomian, sosial, kebudayaan, pendidikan serta politik sebagai akibat semakin modernnya teknologi digital yang digunakan masyarakat (Hamdan, Industri 4.0 : Pengaruh Revolusi Industri Pada Kewirausahaan Demi Kemandirian Ekonomi, Oktober 2018). Dengan demikian menimbulkan suatu pola saling ketergantungan antara sesama anggota masyarakat dengan lingkungannya karena pa (Hamdan, Industri 4.0 : Pengaruh Revolusi Industri Pada Kewirausahaan Demi Kemandirian Ekonomi , Oktober 2018) (Hamdan, Industri 4.0 : Pengaruh Revolusi Industri Pada Kewirausahaan Demi Kemandirian Ekonomi , Oktober 2018)da periode revolusi industri 4.0 lingkungan bukanlah menjadi hambatan untuk anggota masyarakat ketika mereka saling berkomunikasi dan berinteraksi, sehingga terjadi pembauran budaya antar sesama anggota masyarakat.

Pesatnya perkembangan ilmu pengetahuan dan teknologi menyebabkan setiap manusia diharapkan mampu menggali keahlian dan keterampilan calon tenaga kerja yang dimilikinya untuk menunjang kinerja dalam melakukan pekerjaannya sehari-hari. Beberapa ahli memberikan pendapat bahwa bahwa keterampilan tenaga kerja yang unggul secara tidak langsung akan berpengaruh bagi keberhasilan yang memiliki angkatan kerja yang terampil dan ahli di bidangnya (Rohida, 1 Oktober 2018).

Apabila dilihat dalam skema di bawah ini, maka kemampuan berupa keahlian dan keterampilan tersebut dapat dilihat melalui skema kemampuan berbagai jenis sumber daya Indonesia, yaitu : (Majelis Pendidikan Dewan Pendidikan Tinggi Kementrian Riset, 2017)

\section{SUMBER DAYA}

\begin{tabular}{l} 
A. SUMBER DAYA MANUSIA \\
TERDIDIK \\
$\begin{array}{l}\text { (diutamakan lulusan } \\
\text { Perguruan tinggi) }\end{array}$ \\
B. NON SUMBER DAYA MANUSIA \\
SPESIFIK, seperti software, sistim, \\
SOP dll.) \\
C. FISIK BUATAN, seperti hardware), $\begin{array}{l}\text { Etika/values, ciri khas, sikap mental } \\
\text { dan intelektual serta kapabilitas dalam } \\
\text { ilmu pengetahuan merupakan landasan } \\
\text { leadership di masa depan }\end{array}$ \\
$\begin{array}{l}\text { Kebudayaan/culture dan buah pikir } \\
\text { atau ide merupakan dasar } \\
\text { kepemimpinan di masa yang akan } \\
\text { datang. }\end{array}$ \\
\hline $\begin{array}{l}\text { jenis-jenis sumber daya spesifik } \\
\text { lndonesia wajib dipahami oleh }\end{array}$
\end{tabular}
produk evolusi industri 1,2, 3 dan 4 
D. FISIK $\longrightarrow$

Sumber daya alam (SDA), berupa fauna dan flora.

Sumber lainnya, berupa daratan, perairan, ruang angkasa, energi, berbagai macam bahan galian serta benda-benda lainnya.

Kekayaan alam Indonesia mempunyai potensi dasar jauh lebih baik di atas potensi rata-rata bangsa lain

Skema 2. Sumber Daya Indonesia

Dengan demikian pembelajaran di negara ini harus memiliki inovasi dan kreativitas dengan menggunakan perkembangan teknologi sekarang ini dan memiliki nilai karakteristik budaya Indonesia yang ada pula. Di samping itu revolusi industri 4.0 juga menyebabkan terjadinya metamorposis pada sistim sosial pendidikan di Indonesia (Abdul Rohman, Yenny Eria Ningsih, 29 September 2018). Pendidikan yang diperlukan adalah pendidikan yang harus memenuhi kebutuhan sumber daya manusia (SDM) agar manusia dapat berfungsi menjadi sumber daya yang lebih baik dalam lingkungan masyarakat (Iswan, Herwina, 24 Maret 2018).

Selain hal tersebut di atas, juga terdapat tiga aspek yang mendasar yang harus diperhatikan, yaitu :

1. Kualitas, yaitu kemampuan menciptakan manusia Indonesia yang mempunyai daya saing yang unggul supaya dapat memenuhi permintaan kebutuhan pasar tenaga kerja yang berbasis teknologi digital.

2. Kuantitas, yaitu membentuk warga negara Indonesia yang mempunyai kapabilitas untuk memenuhi standar keperluan industri.

3. Distribusi pekerja yang produktif yang mempunyai keahlian dan keterampilan, namun pada prakteknya di lapangan jumlahnya sampai dengan saat ini tidak merata.

(Haryono, 5 Mei 2018)

Sehubungan dengan hal tersebut, maka setiap pekerja (SDM) berkewajiban memenuhi standar kemampuan atau kompetensi, sehingga memungkinkan mereka untuk bersaing ketika memasuki lapangan kerja (Utomo, 2010). Istilah kata "kompetensi" berasal dalam bahasa Inggris, yaitu : "competencies" atau "competence", yang memiliki pengertian sebagai kapasitas atau juga berarti kecakapan seseorang. Kemudian istilah kompetensi tersebut digunakan masyarakat untuk bermacam-macam tujuan dengan makna yang beragam seperti yang dipakai dalam lingkup manajemen sumber daya manusia.

Pengertian kompetensi tersebut yang identik sebagai keterampilan dan kapabilitas atau keahlian seseorang tersebut, selanjutnya menurut Robert A. Roe didefinisikan menjadi "competence is defined as the ability to adequately perform a task, duty or role. Competence integrates knowledge, skills, personal values and attitudes. Competence builds on knowledge and skills and is acquired through work experience and learning by doing. " Berdasarkan Robert A. Roe tersebut kompetensi merupakan keterampilan seseorang dalam menjalankan pekerjaan tertentu serta juga kemampuan mengimplementasikan pengetahuannya, ketrampilannya, memiliki tingkah laku serta etika yang baik yang diperolehnya 
berdasarkan pengalaman yang dimiliki seseorang dan proses pembelajaran yang telah dialaminya.

Pada hakikatnya masing-masing individu memiliki kemampuan untuk maju dan berkembang dengan cara mengembangkan potensi yang terdapat dalam dirinya melalui peningkatan ilmu pengetahuan. Kompetensi tersebut dapat menunjang kinerja seseorang dalam melakukan pekerjaannya sehari-hari. Walaupun di lapangan banyak ditemui para pekerja yang tidak bersedia untuk melanjutkan pendidikannya ke jenjang berikutnya, misalnya Strata Satu dengan berbagai alasan yang dikemukakan berupa faktor kematangan umur, tidak mempunyai kesempatan waktu yang tersisa untuk terus belajar, kapasitas belajar yang menurun serta alasan bahwa sebentar lagi mencapai periode untuk beristirahat dari bekerja atau pensiun. Sehingga dengan demikian pekerja tersebut seolah-olah memang tidak memiliki keinginan untuk berkembang untuk meningkatkan kariernya dan kinerjanya di tempat kerja yang dimilikinya. Oleh karena itu hal yang terpenting dalam mewujudkan kompetensi, yaitu kemauan untuk giat bekerja dan memiliki tekad agar terus menerus belajar dengan tidak dibatasi dengan pikiran yang pesimis.

Oleh sebab itu sumber daya manusia (SDM) harus memiliki kerajinan, loyalitas/kesetian dan kreativitas dalam pekerjaan dan memiliki pemikiran yang positif serta meninggalkan tingkah laku yang tidak baik dalam bekerja, seperti sikap menyelesaikan pekerjaan dalam waktu yang melampaui jadwal penyelesaikan pekerjaan maupun tidak bersemangat untuk datang kantor. Sifat tersebut mengakibatkan pekerja yang bersangkutan tidak dapat berkembang dan tentu saja akan mempengaruhi kinerjanya. Oleh sebab itu sumber daya manusia (SDM) harus memiliki pemikiran yang positif untuk meningkatkan kinerjanya.

Dengan demikian dapat dikatakan bahwa kompetensi adalah basic karakter yang termasuk kepribadian yang melekat pada individu dan perilaku individu tersebut yang berkaitan dengan berbagai situasi dan tugas pekerjaannya. Sifat dasar tersebut merupakan pendorong agar memiliki prestasi dan keinginan untuk terus berusaha. Apabila terdapat ketidaksesuaian kompetensi tersebutlah yang membedakan antara seorang individu yang memiliki prestasi dengan individu yang tidak memiliki prestasi. Kompetensi yang terbatas tersebut dan kompetensi yang unggul untuk melaksanakan pekerjaannya tersebut, sehingga dapat dijadikan acuan dalam memilih calon pegawai (personal selection), merencanakan perpindahan pekerjaan karyawan (succession planning) dan melakukan evaluasi kinerja (performance appraisal) serta peningkatan kemajuan diri (development).

Jadi kompetensi merupakan kemampuan menguasai ilmu pengetahuan, keterampilan dan keahlian, etika dan tingkah laku yang berkaitan dengan hasil kerja melalui kemampuan berpikir dan bertindak yang dimiliki individu sesuai dengan profesi pekerjaan yang dimilikinya. Kompetensi juga merupakan kemampuan melaksanakan pekerjaan tertentu berdasarkan keterampilan dan ilmu pengetahuan yang berkaitan dengan pekerjaan yang akan dilakukan. Sehingga kompetensi merupakan keterampilan atau ilmu pengetahuan yang dimiliki sumber daya manusia (SDM) dalam bidang pekerjaan tertentu yang merupakan karakter dasar dari manusia sesuai dengan hasil kerja yang memuaskan.

Dalam hal ini maka titik berat kompetensi adalah kemampuan menggunakan ilmu pengetahuan dan penguasaan tugas dalam bekerja untuk memperoleh hasil kerja yang maksimal. Jadi kompetensi merupakan kemampuan penguasaan pengetahuan dan keahlian milik seseorang dan faktor internal lainnya agar mampu 
melakukan suatu pekerjaan. Sehingga dapat dikatakan juga kompetensi, yaitu kesanggupan menyelesaikan pekerjaan sesuai dengan pengetahuan dan keterampilan yang dikuasai oleh seseorang.

Menurut Mathis dan Jackson, kompetensi berupa penguasaan ilmu pengetahuan dan keterampilan terlihat nyata (visible) dan biasanya merupakan karakter yang melekat pada manusia. Kompetensi merupakan penguasaan pengetahuan dan keahlian cenderung dapat berkembang, seperti melalui strategi training untuk memperbaiki kualitas pegawai serta tidak memerlukan biaya besar untuk menguasainya.

Kompetensi penguasaan pengetahuan tersebut, yaitu kemampuan yang berkaitan dengan tugas pekerjaan yang penting bagi sumber daya manusia (SDM) untuk dilaksanakan. Menurut Gibson dalam hal ini merupakan tingkat pemahaman secara verbal seorang karyawan mengenai hal-hal yang diketahuinya melalui latar belakang metode pembelajaran. Penguasaan yang baik mengenai pekerjaannya, seseorang pada dasarnya tentu saja memperbaiki kapasitas pekerjaan seseorang. Seandainya seorang karyawan mempunyai kemampuan menyelesaikan perkerjaannya, maka pegawai yang bersangkutan sudah pasti dapat menuntaskan pekerjaannya tersebut dengan result yang efektif pula, begitu juga sebaliknya.

Kemudian kompetensi penguasaan skill pekerjaan, yaitu pemahaman seseorang yang berkaitan dengan pekerjaan yang akan dilakukannya serta dipakainya pada waktu yang tepat pula, seperti seorang staff yang bertugas memberikan pelayanan publik harus memiliki perilaku yang professional, memiliki keterampilan yang profesional dan kehidupan yang profesional pula.

Oleh karena itu dapat disimpulkan bahwa semakin baik skill seseorang maka, semakin efektif pula kekuatan serta pikirannya pada saat melakukan pekerjaannya. Dalam hal ini maka pendidikan dan pelatihan yang dimiliki seseorang akan membuatnya menjadi pegawai yang terampil dan dibutuhkan dan dengan memiliki keterampilan tersebut dapat meningkatkan seseorang menjadi lebih memiliki rasa percaya diri dalam melakukan pekerjaannya.

Apabila kompetensi ini ditarik garis penghubung dengan kinerja dapat digambarkan menjadi pola alur kausa yang menggambarkan sasaran, karakter, konsep seseorang dan kompetensi penguasaan pandangan yang merupakan perkiraan hasil kerja yang terdiri atas niat, perbuatan dan final result. Apabila keinginan kuat untuk memiliki performa dan mencapai hasil yang semaksimal mungkin. Hal tersebut menunjukan adanya kemungkinan perilaku kewirausahaan, menentukan tujuan dan sikap bertanggung jawab atas hasil akhir serta kemampuan untuk mengambil risiko yang dapat diprediksi terlebih dahulu.




Berdasarkan pola dalam Gambar 3 tersebut, maka pemahaman adalah element dasar karakter seseorang yang harus ditingkatkan untuk mengembangkan hasil kerja menjadi lebih baik. Hal tersebut sejalan dengan definisi dari ilmu pemahaman tersebut, yaitu :

1. Tacit Knowledge.

Konsep tacit knowledge tersebut ditemukan oleh seorang ahli filsafat yang bernama Polanyi pada tahun 1998. Menurut Polanyi bahwa tacit knowledge merupakan ilmu pengetahuan manusia yang berdasarkan fakta yang diketahui manusia. Sedangkan menurut Dalkir bahwa tacit knowledge memiliki sifat untuk beradaptasi dalam menghadapi situasi yang baru, yaitu mampu berkerjasama, saling berbagi visi dan misi, sehingga dapat mentransfer budaya, pelatihan maupun mentoring agar dapat meneruskan ilmu pengetahuan dan pengalaman dari satu orang kepada orang lainnya. Oleh karena itu berlandaskan pemahaman di atas, maka interpretasi dari tacit knowledge merupakan pengetahuan yang dimiliki seseorang, sehingga memiliki sifat personal yang didapatnya melalui pengalaman yang dimiliki seseorang tersebut walaupun ilmu pengetahuan tersebut susah untuk diberitahukan kepada orang lain.

2. Explicit Knowledge

Explicit knowledge lebih ke arah konvensional serta sistimatis, sehingga tidak sukar untuk ditransfer pada orang lain. Pengaplikasian explicit knowledge tersebut tidaklah sulit karena ilmu pengetahuan yang didapat berbentuk tertulis atau rangkuman dokumentasi dari berbagai pernyataan, sehingga setiap pegawai dapat mempelajarinya sendiri dengan mudah. Misalnya prosedur kerja (job description) dan berbagai macam teknologi atau standard operation procedure (SOP) yang dibuat untuk menjaga kualitas produk dan hasil pekerjaan.

Pada hakikatnya kemampuan kinerja setiap orang tidaklah sama dengan orang lain sebab setiap pegawai mempunyai kemampuan yang tidak sama dan bergantung dari kemampuan, usaha dan kesempatan yang dimiliki seseorang. Kinerja dalam hal ini seperti hasil kinerja, performa kerja atau tingkat kesuksesan pegawai dalam melaksanakan kewajibannya dan bertanggung jawab.

Kinerja tergantung oleh beberapa hal yang bersumber dari dalam dan luar diri seseorang. Performa menjadi execellent apabila didukung oleh faktor internalnya, seperti kemampuan yang tinggi dan kerja keras serta didukung pula oleh faktor eksternal, seperti kebetulan memperoleh pekerjaan yang mudah, faktor keberuntungan (good luck), memperoleh pertolongan dari rekan kerja yang lain dan memiliki pemimpin yang baik. Dalam hal ini begitu juga sebaliknya apabila kedua faktor tersebut tidak dimiliki, maka kinerja seseorang menjadi tidak baik. Oleh karena itu untuk selanjutnya beberapa aspek yang berpengaruh pada performa kerja akan diuraikan menjadi : 




Sumber : Porter-Lawler dalam Gibson

Gambar 4. Skema Model Kinerja

Apabila kembali merujuk pada diagram umum sumber daya dalam Gambar 2 yang telah dikemukakan, maka calon tenaga kerja Indonesia harus dijadikan perspektif bahwa kehidupan harus menciptakan pekerja yang unggul serta mempunyai nilai (values), karakter serta tingkah laku dan etika. Di samping itu harus menguasai perkembangan pengetahuan dan mempertahankannya serta menjaga budaya Indonesia dan memiliki sikap sebagai leader.

Selanjutnya di dalam periode revolusi industri 4.0, maka manufaktur maupun industri akan dijalankan secara digital yang disebut industri 4.0 yang meliputi bermacam-macam teknologi, seperti 3 Dimensi Printing sampai dengan robotik, ditemukan berbagai jenis material dan sistim produksi digital. Keuntungan negara maju terutama negara-negara di Eropa Barat, maka industri 4.0 merupakan cara dalam memperoleh kembali daya saing infrastruktur. Sedangkan bagi Indonesia sebagai negara industri, maka melalui industri 4.0 rantai suplai produksi akan lebih disederhanakan guna mensiasati cost biaya pemakaian tenaga kerja yang semakin mahal.

Produsen raksasa seperti Intel atau General Electric $(G E)$ memasuki revolusi industri 4.0. dengan membentuk Industrial Internet Consortium (IIC) dengan menjalin kerjasama bersama IBM, AT\&T serta Cisco. Walaupun kelihatannya merupakan sebuah janji, namun masih terdapat bidang lain akan dilaksanakan agar terwujud industri yang modern dengan jumlah yang besar, seperti kebijakan dan berbagai peraturan perundangan yang mendukung dimana para pembuat kebijakan tersebut harus memastikan aliran informasi ini menjadi wujud dari bagian inti industri 4.0 yang bersifat dinamis melalui cara yang terbuka serta jelas melampaui jaringan suplay data antar wilayah.

Dengan demikian yang menjadi tantangan bagi labor market dalam periode revolusi industri 4.0 adalah penggunaan sistim digital melalui berbagai bidang usaha dengan menggunakan teknologi dan informasi yang modern. Ciri khas revolusi industri 4.0 tersebut seperti bersifat digital, optimal dan permintaan produk, bersifat otomatis serta adaptasi penggunaan instrumen dan alat kerja dengan manusia. Di samping itu kegunaan, yaitu produk jasa dan bisnis, automatic data exchange and communication serta menggunakan metode ilmiah yang berbasis digital. Ancaman yang telah dikemukakan itu harus dapat dihadapi dengan 
melakukan perubahan sumber daya manusia (SDM) dengan memperhatikan iklim bisnis dan industri yang selalu mengalami perubahan.

Demikian juga terdapatnya perubahan jabatan struktural dalam organisasi. Hal yang paling mendasar, yaitu keterampilan dan kompetensi angkatan kerja yang harus disesuaikan dengan permintaan labor market yang terus maju. Sehingga dalam hal tersebut bidang pembelajaran dan dunia pabrikasi harus berusaha memperbaiki strategi transformasi industri melalui cara memperhitungkan kemajuan bidang sumber daya manusia sebab tranformasi kemajuan pabrikasi akan terwujud apabila sumber daya manusianya memiliki kompetensi dan berkualitas.

Memenuhi permintaan periode revolusi industri 4.0 harus disertai tidak hanya dengan pemikiran metode kemampuan calon pekerja yang terdahulu dimana mereka hanya memiliki pengetahuan dibidang baca, tulis serta hitung. Sehingga menurut Aoun agar dapat menciptakan calon pekerja dengan kemampuan untuk bersaing pada industri 4.0, maka kurikulum pendidikan disesuaikan agar outputnya dapat menguasai kemampuan yang lebih baik, yaitu :

1. Kemampuan data, yaitu mampu memahami, menganalisa serta memanfaatkan pengetahuan mengenai bit data dalam dunia digital.

2. Kemampuan digital, yaitu kemampuan untuk memahami proses bekerjanya instrumen, pemahaman penerapan digital, seperti coding, artificial intelligence dan engineering principles.

3. Kemampuan calon pekerja sebagai diri manusia, yaitu kemampuan berkomunikasi, kreativitas serta sifat positif manusia lainnya.

Berdasarkan sudut pandang kemampuan calon pekerja tersebut bertujuan supaya calon pekerja mampu menyesuaikan diri dengan calon pekerja lainnya yang selalu bersifat terus berubah. Sehingga dengan demikian setiap lembaga pendidikan harus memiliki suatu cara dalam mengembangkan aspek kognitif manusia, yaitu : kemampuan berfikir kritis dan sistimatis (higher order mental skills). Sebab dalam industri 4.0 yang menjadi modal dasar sumber daya manusia (SDM) adalah : kepemimpinan (leadership) dan kemampuan menjalankan pekerjaan bersama kelompok (team work), keterampilan dan kedewasaan dalam budaya (cultural agility) dan menyadari bahwa setiap pekerja berasal dari budaya yang beraneka ragam serta kemampuan kewirusahaan (entreprenurship) yang berbeda termasuk juga sociopreneurship.

Sociopreneurship atau sosial entrepreneurship merupakan bentuk usaha yang tidak mencari dan tidak mendapatkan keuntungan semata-mata (Dwianto, Maret 2018), namun orientasi bisnis yang tidak mencari keuntungan ini kemudian berubah seiring dengan perkembangan waktu. Selanjutnya menjadi berkembang pesat dalam segala bidang usaha, antara lain education, health, fintech, fishery, women empowerment, environment, agriculture serta tourism (Maulinda, 2018). Di dalam sosial wirausaha ini menekankan relasi kemasyarakatan, ekonomi, lingkungan dan budaya. Dengan kata lain dalam sosial wirausaha pelaku usaha akan merubah sebuah kegagalan menjadi peluang bisnis baru yang menguntungkan dengan melakukan perekrutan orang-orang yang mengalami kegagalan kemudian memberikan motivasi, sehingga terjadi perbaikan pada orang tersebut (Reindrawati, 2017).

Kesimpulan yang dapat diambil bahwa di dalam kegiatan usaha apapun modal yang fundamental dari sumber daya manusia (SDM) harus tetap dipertahankan, yaitu memiliki pribadi yang luar biasa (extravenous), 
menyenangkan (agreeableness), memiliki nurani yang baik (conscientiousness), memiliki kestabilan mental (emotional stability) serta kemampuan menerima pengetahuan yang modern (openness to experience) yang disertai dengan aspekaspek keberhasilan yang lainnya seperti kecerdasan emosional, kecerdasan spiritual yang meliputi kesadaran diri (self awareness), management perasaan (emotional management), motivasi diri (self motivation), perasaan tenggang rasa (empathy), mengelola hubungan baik (managing relationship), keterampilan berkomunikasi (communication skills) dan kepribadian (personal style). Kategorisasi tacit dan explicit knowledge seperti yang telah disebutkan Polanyi juga harus menjadi perhatian dalam era industri 4.0.

Akhir kata upaya peningkatan kinerja sumber daya manusia (SDM) juga harus dilakukan oleh setiap organisasi degan cara yang berbeda yang dapat berupa perbaikan kualitas sumber daya yang dimilikinya, seperti menentukan kemampuan masing-masing pegawai, menyesuaikan banyaknya pekerja sesuai dengan pekerjaan yang harus dikerjakan, memenuhi sarana dan prasarana organisasi, memperbaiki sistim management dan memberikan perhatian kepada semua pegawai serta menciptakan atmosphere pekerjaan yang baik dan menyenangkan untuk perusahaan.

\section{KESIMPULAN}

Terdapat tiga aspek yang mendasar yang harus diperhatikan dalam revolusi industri 4.0, yaitu : kualitas, kuantitas dan distribusi calon pekerja yang unggul berkualitas serta mempunyai kemampuan yang diperlukan agar dapat bersaing melalui pasar tenaga kerja. Oleh karena itu dalam revolusi industri 4.0, maka setiap calon pekerja harus menguasai ilmu pengetahuan, memiliki keterampilan, nilai dan tingkah laku yang behubungan dengan kinerja melalui kemampuan berpikir dan bertindak sesuai dengan profesi pekerjaan yang dimilikinya masing-masing.

Calon pekerja tersebut pada periode revolusi industri 4.0 juga berkewajiban memiliki kinerja, seperti job result, kinerja dalam bekerja maupun kesuksesan pekerja dalam menyelesaikan seluruh kewajiban yang telah diberikan kepada pekerja yang bersangkutan, walaupun kinerja setiap orang tidaklah sama tergantung dari kemampuan masing-masing usaha dan kemampuan yang berbeda-beda.

Di samping itu kemampuan calon pekerja yang lainnya harus tetap dipertahankan, yaitu extravenous, agreeableness, conscientiousness, emotional stability dan openness to experience beserta aspek-aspek keberhasilan yang lain seperti kecerdasan emosional, kecerdasan spiritual yang meliputi kesadaran diri (self awareness), management perasaan (emotional management), motivasi diri (self motivation), perasaan tenggang rasa (empathy), mengelola hubungan baik (managing relationship), keterampilan berkomunikasi (communication skills) dan kepribadian (personal style), demikian juga tacit dan explicit knowledge juga harus turut diperhatikan dalam periode revolusi industri 4.0.

\section{DAFTAR PUSTAKA}

Abdul Rohman, Yenny Eria Ningsih. 29 September 2018. Pendidikan Multikultur : Penguatan Identitas Nasiobal Di Era Revolusi Industri 4.0. Seminar Nasional Multidisiplin. Jombang : UNWAHA. 
Alamsyah, R. November 2018. Analisis Dampak Industri 4.0 Terhadap Sistem Pengawasan Ketenaganukliran Di Indonesia. Jurnal Forum Nuklis (JFN), Volume 12, No. 2, 47-53.

Baiquni, M. Januari 2009. Revolusi Industri, Ledakan Penduduk dan Masalah Lingkungan. Jurnal sains dan Teknologi Lingkungan, Volume 1, No. 1, 3859.

Dwianto, A. S. Maret 2018. Sosial Entrepreneur Ship : Inovasi Dan Tantangan Di Era Persaingan Bebas. Majalah Ilmiah BIJAK, Vol. 15 No. 1, 68-76.

Hamdan. Oktober 2018. Industri 4.0 : Pengaruh Revolusi Industri Pada Kewirausahaan Demi Kemandirian Ekonomi. Jurnal Nusamba, Vol. 3 No. $2,1-8$.

Hamdan. Oktober 2018. Industri 4.0 : Pengaruh Revolusi Industri Pada Kewirausahaan Demi Kemandirian Ekonomi . Jurnal Nusamba, Vol. 3 No. $2,1-8$.

Haryono, S. 5 Mei 2018. Re Orientasi Pengembangan SDM Era Digital Pada Revolusi Industri 4.0. The National Conference on Management and Business (NCMAB) . Yogyakarta: Direktorat Pascasarjana Universitas Muhammadiyah.

Hoedi Prasetya, Wahyudi Sutopo. Januari 2018. Industri 4.0 : Telaah Klasifikasi Aspek dan Arah Perkembangan Riset. J@ti Undip : Jurnal Teknik Industri, Vol. 13, No. 1, 17-26.

Iswan, Herwina. 24 Maret 2018. Penguatan Pendidikan Karakter Perspektif Islam Dalam Era Milenial IR 4.0. Prosiding Seminar Nasional Pendidikan Era Revolusi "Membangun Sinergitas Dalam Penguatan Pendidikan Karakter Pada Era IR 4.0" (hal. 21-42). Jakarta: Universitas Muhammadiyah.

Maemunah, H. Sabtu, 29 September 2018. Kebijakan Pendidikan Pada Era Revolusi Indonesia. Prosiding Seminar Nasional Lembaga Penelitian dan Pendidikan (LPP) Mandala (hal. 1-9). Mataram: Universitas Muhamadiyah Mataram.

Majelis Pendidikan Dewan Pendidikan Tinggi Kementrian Riset, T. d. 2017. Memandang Revolusi Industri Dan Dialog Pendidikan Karakter Di Perguruan Tinggi Indonesia. Jakarta : Direktorat Pembelajaran Direktorat Jenderal Pembelajaran dan Kemahasiswaan Kementrian Riset, Teknologi dan Penddikan Tinggi.

Maulinda, K. 2018. Proses Pengembangan Sosial Entrerprise Agri Culture Studi Biografi Pada Agradaya. Jurnal Studi Pemuda, Vol 7 No. 2, 133-143.

Reindrawati, D. Y. 2017. Tantangan dan Implementasi Social Entrepreneurship Pariwisata Di Pulau Madura. Jurnal Masyarakat, Kebudayaan dan Politik, Vol 30 No. 3, 215-228.

Rohida, L. 1 Oktober 2018. Pengaruh Era Revolusi Industri 4.0 Terhadap Kompetensi Sumber Daya Manusia. Jurnal Manajemen Bisnis Indonesia, 114-136.

Suwardana, H. 2017. Revolusi Industri 4.0 Berbasis Revolusi Mental. JATI UNIK, Vol. 1 No. 2, 102-110.

Utomo, H. 2010. Kontribusi Soft Skill Dalam Menumbuhkan Jiwa Kewirausahaan. Among Makarti, Vol. 3, No. 5, 95-104. 